\title{
Ship Recycling: An Important Mile Stone for India
}

\author{
Nanda Gopal K. Reddy ${ }^{1 *}$ and N. Manoharan ${ }^{2}$ \\ 'Centre for Maritime Research, Dept. of Marine Engineering, AMET University, \\ Chennai, India; kngreddy@gmail.com \\ 2Director Research, AMET University, India; Directorresearch@ametuniv.ac.in
}

\begin{abstract}
Ship recycling has been considered as the best practice to re-use the components to cut down the principle ship building cost and to save time. The current state of re-use and if combine the art of technology with the demands of beneficial developments from the maritime industrial sector; throughout the world has modified the status of 'ship breaking'7 from ship scrap business. The modern industry responsible for dismantling of ships for recycling or reusing must follow the principles of recycling. The regulatory body has to formulate a set of regulations for re-testing and blend them as a substitute and equal to the new products in order to sustain throughout its life span with the engineering quality. The background history, structure and enforcement of the 2009 Hong Kong International Convention on the Safe and Environmentally Sound Recycling of Ships have been analyzed. The 2009 Hong Kong Convention establishes control and enforcement instruments related to ship recycling, determining the control rights of Port States and the obligations of Flag States, Parties and recycling facilities under its jurisdiction. The Convention also controls the communication and exchange of information procedures, establishes a reporting system to be used upon the completion of recycling, and outlines an auditing system for detecting violations. Thorough knowledge regarding these background procedures in ship recycling is essential for examining and understanding the industrial business operations associated with it. The paper elaborates ship recycling and will eventually influence the final acceptance of this Convention by the international community.
\end{abstract}

Keywords: Growth, India, Rebuilding, Re-cycling, Ship

\section{Introduction}

The ship recycling industry of India has come a long way since its inception in 1982. At the beginning, it started with recycling 5 ships in the year 1982 to recycling ${ }^{1}$ more than 500 ships in the year 2012. In the last three decades, the industry has grown by 100 times. There were ups and downs at different points of time due to cyclic nature of the shipping, shipbuilding and ship recycling industry.

India entered ship recycling when the shipping cycle was at peak during the oil boom of ' 80 s.

However, soon the freight market began to fall leading to larger supply of ships for recycling. Larger supply of ships provided additional opportunity for India which gradually started gaining larger market share for recycling of ships.
Post '90s, other countries such as Pakistan, Bangladesh, which were not very prominent in the ship recycling industry and had lost substantial share to India, began to recapture the market by aggressive bidding. By mid ' 90 s, despite the competition from the neighbouring countries, India had gained substantial share in the ship recycling market and every year India used to recycle in the range of 300 ships (Figure 1).

Post 2003, there was again a bull run for the shipping and shipbuilding industry. This reduced the ship availability for recycling industry in India. For five years, from 2004 to 2008, the industry remained subdued for recycling ships.

The global market share of ship recycling yard from Gujarat has fallen from close to $50 \%$ by DWT and 60\% by number in the year 1996 to $31 \%$ by DWT and $44 \%$ by

*Author for correspondence 


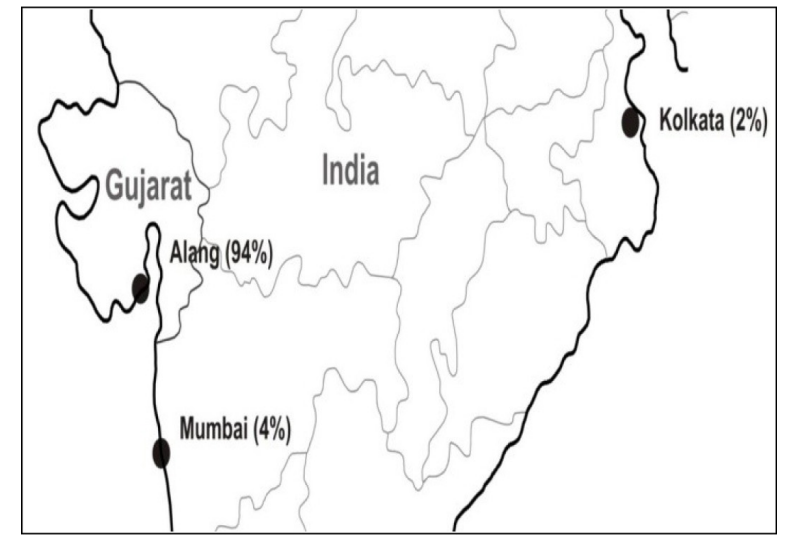

Figure 1. Ship Recycling Locations in India.

number in the year 2013. One of the reasons for fall in ship recycling volume post 2003 is Supreme Court guidelines on recycling of tankers. India has been losing tanker volumes to countries which have lesser environment restrictions, such as Bangladesh and Pakistan.

The shipping industry has a potentially negative impact on the marine environment and some economic disadvantages. In addition, if there is no appropriate integrated system for the recycling or reusing of ship-related steel, machines, auxiliaries and even furnishings, such materials will remain unused and useless to the economy at the end of a ship's life cycle. In this respect, ship-recycling facilities contribute to sustainable development and represent an environment friendly way to dispose of ships $^{8}$ and to economically integrate their life chains. Ship recycling costs are comparatively higher in the European Union (EU) and the United States of America (USA) than in Asia because of the strict regulations relating to environmental issues and occupational safety and health issues. Thus, ship-recycling facilities in the EU and the USA are not economically viable.

At the end of a ship's life cycle, the ship contains not only various recyclable materials but also a range of hazardous and toxic substances ${ }^{5}$. In Europe ${ }^{5}$ and in Member States of the Organization for Economic Co-operation and Development (OECD), materials that contain hazardous and toxic substances are subjected to monitoring, and their disposal is strictly regulated. Most of those substances in ships are defined as hazardous and toxic under the existing 1989 Basel Convention on the Control of Trans boundary Movements of Hazardous Wastes and their Disposal (1989 Basel Convention).

The reality is that, currently, the global shipping industry relies on developing countries to dispose of decommissioned ships through the process of ship recycling. As a result, the ship recycling industry avoids the burden of complying with the high cost standards in developed countries in order to manage the hazardous wastes involved in decommissioning.

Subsequently, occupational safety and health issues emerge-particularly in association with the dismantling of beached ships in India, Bangladesh and Pakistan ${ }^{10}$. Ship-recycling workers live under the constant threat of occupational accidents due to the inherent risks of ship dismantling. In the above-mentioned countries, most of the workers do not wear protective equipment such as helmets, masks or goggles, and there are no warning signs of danger. Most of the workers have no occupational ${ }^{10}$ training in working with blowtorches or with the hazardous substances involved in ship recycling. Furthermore, many workers do not wear safety goggles to protect their eyes from the sparks. The paint and coatings cladding the ship's hull may be flammable and/or may contain toxic ingredients such as polychlorinated biphenyls (PCBs), heavy metals and pesticides such as tributyl tin (TBT) ${ }^{6}$. Toxic fumes are released during the blowtorch-cutting process and afterwards while the paint and coatings may continue to smolder. The workers who use cutting torches routinely inhale the toxic fumes from, for example, the steel coated with toxic paints.

The rise of environmentalism has influenced the development of policies in developed countries and international organizations, particularly the International Maritime Organization (IMO), the United Nations dedicated legislator of the global shipping industry since the catastrophic maritime catastrophes that took place in the $1960 \mathrm{~s}^{4}$. The IMO has been challenged with establishing a globally applicable and comprehensive maritime environmental ${ }^{6}$ legal system to achieve the goal of sustainable development. Taking into consideration various shipping activities and sustainable development, the maritime environmental.

\section{Current Scenario}

India continues to maintain more than $30 \%$ share of global ship recycling volume by DWT and more than $40 \%$ share by numbers. In terms of DWT, India recycled $33 \%$ ships in 2012 followed by Bangladesh's 24\%, China's $20 \%$, Pakistan's $16 \%$ and others $7 \%$ (Figure 3). By number of ships, India's share was $40 \%$ followed by China's $18 \%$, Bangladesh's $17 \%$ and others $17 \%$. India recycled ships 
equivalent to 18 million DWT corresponding to close to 500 ships. Going forward, there is a need to restrict falling market share and increase the dominance of Indian ship recycling industry to gain larger share.

In order to recapture the losing market share in ship recycling sector, India have reviewed the industry (Figure 2) and have to upgrade its work process and provide recycled products with high value addition. High value added recycled steel, equipments and other products would command premium in the market, which would offset the additional cost of undertaking environment ${ }^{4}$ friendly ship recycling.

Similar to shipping and shipbuilding industry, ship recycling industry is driven by industry cycles. As can be seen in the chart below, Ship Recycling volume from 1996 to 2003 remained in the range of 600 ships a year

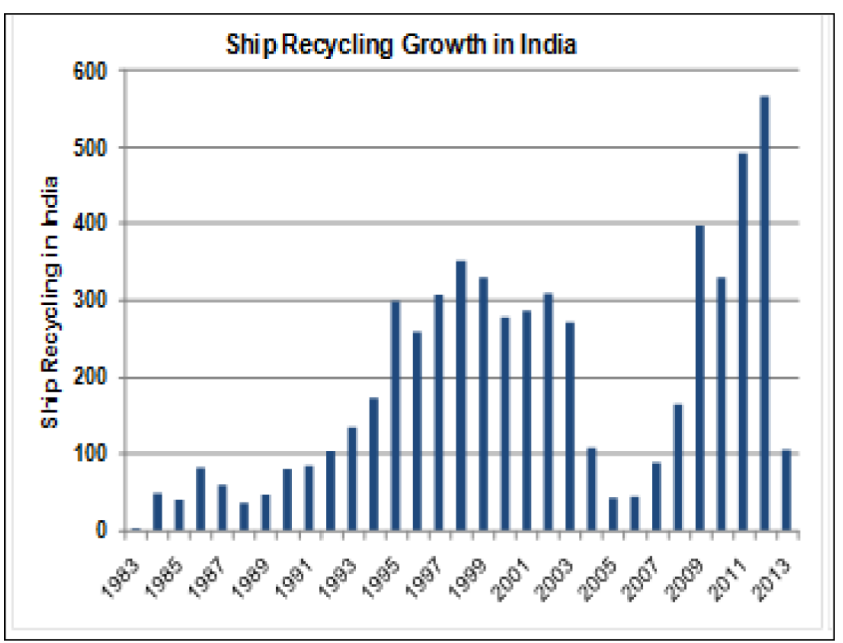

Figure 2. Review of ship recycling growth in India.

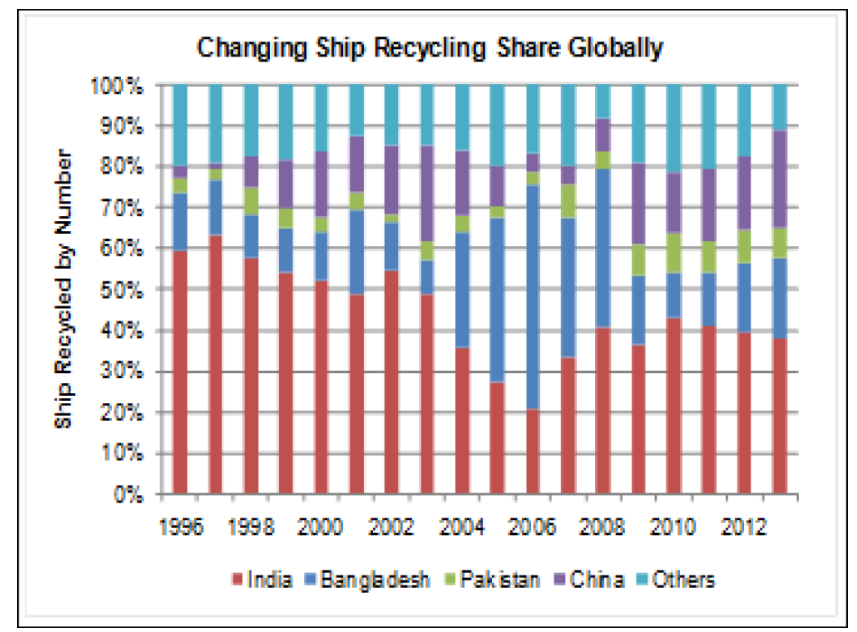

Figure 3. Trends in ship recycling review.
(Figure 5) or varied between 18 million DWT to 30 million DWT. From year 2004 to 2008 saw low activity in the Ship Recycling sector due to robust economy and buoyant freight rate and less ship got recycled.

Similar to shipping and shipbuilding industry, ship recycling industry is driven by industry cycles. As can be seen in the chart below, Ship Recycling volume from 1996 to 2003 remained in the range of 600 ships a year or varied between 18 million DWT to 30 million DWT. From year 2004 to 2008 saw low activity in the Ship Recycling sector due to robust economy and buoyant freight rate and less ship got recycled.

Majority of the ships that get recycled in India are cargo ships. This has been evident that the number of ship recycled in India has a higher share compared to DWT. Ship recycling activity is a volume play. Recycling of cargo ships are driven by steel weight, whereas recycling of service ships are driven by value of equipments and machinery, which can be refurbished ${ }^{11}$ and reused in future ships.

Ship recycling in Asian countries such as India, Bangladesh, Pakistan and China are Figure 4 predominantly driven by steel. This leads to higher \% of cargo ships getting scrapped in Asian countries including India.

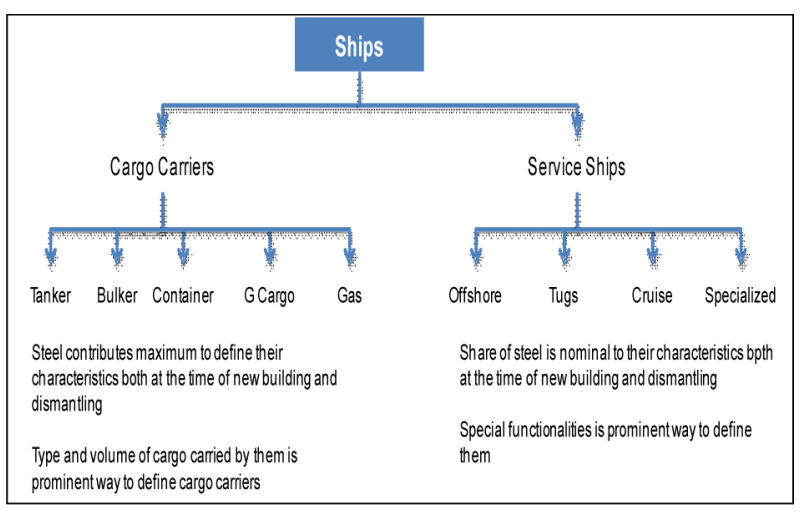

Figure 4. Type of ships and trades views.
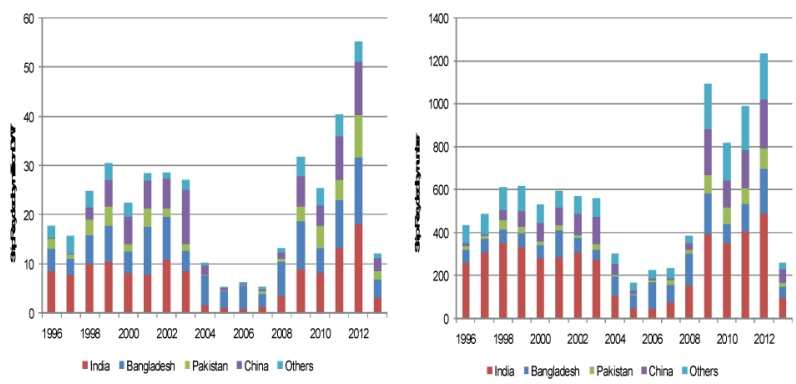

Figure 5. Growth of ship recycling. 
As, service vessels like offshore supply vessel, cruise vessels, etc have lower share of steel and therefore in LDT terms the usable steel extracted from these ships is substantially lower.

\section{Prominent Methods of Recycling}

There are two prominent methods of recycling a ship, which are as follows:

- Beaching

- Dry-docking

India uses beaching method for recycling of ship. This method has been successful in India, especially at Alang in Gujarat due to very high tidal variation in the region. At high tide, ship at its full thrust is allowed to approach the shore of the recycling yard and be beached. It could also be pulled by winches, if the ship is not under its own propulsion. Sometimes, even while operating on its own propulsion, winches are used to pull ships further inside.

At low tide, when the water recedes, the ship settles down. Thereby ship is recycled manually from top to bottom symmetrically. Western countries do not consider beaching method to be environment friendly. Hence, they mostly use either at afloat or at dry-dock for safe ${ }^{3}$ recycling of ships. However, Supreme Court has laid guidelines for safe recycling of ship using beaching method. Under beaching method in India, pre-inspection and removal of hazardous waste is essential.

Compared to all the 3 methods, it is advised that a ship recycling yard follow the afloat method or drydocking, as it limits the extent of open space that will be exposed to the waste and other harmful materials that result from recycling. Beaching method is employed only in India, Pakistan and Bangladesh. Recycling yards in China employ afloat method, and they are being able to capture maximum market share of ship recycling industry globally. European Union nations use slipway and docking method but OECD and non-EU nations use landing and afloat. All the nations that use methods other than Beaching do so mostly because of strict environment regulations ${ }^{9}$ and a disciplined approach to following these.

The current method of recycling ship using beaching method not only saves cost in terms of infrastructure but also facilitates smooth recycling operation that is most economical and eco-friendly. Afloat method possess some technical difficulty. It is very difficult to balance the ship as parts are being cut, and then there's the issue of maintaining gravity in a afloat method. Also, for instance, waste water generated from hot work will directly find its way into the sea. Along with waste water, other wastes are likely to make their way into this basin of the port if they are not carefully dealt with. In contrast, in the beaching method, more amount of control can be exercised during cutting operations. Still for future development it is advisable to create infrastructure pertaining to afloat or dry-dock method.

\section{Direct Utilisation - Recycled Items}

A large number of items generated from ship recycling yard can be directly utilized by bare minimum value addition. These items would include bulk hardware items such as anchors, chain, wires, pulley, iron and steel items, steel, glass containers, etc( Table 1).

A ship has several cargo handling equipments on board. These items need not be recycled fully. They would need to be refurbished and repaired to extend their operation life and performance. The material handling equipments such as cranes, cargo gears, davits, pulleys, etc can be used for wide range of applications both in marine and non-marine sector.

Items extracted from ship at the time of recycling could be used in existing ship. Marine equipments are highly robust and have a very long lifespan. This has led to many shipping companies depending on these equipments from ship recycling yard due to immediate availability, lower cost of acquisition and lower downtime. Items generated from ship recycling yard come in handy in case of sudden breakdown of parts. With the use of these equipments and machinery, the ship downtime can be reduced to a large extent. Getting a new item is more time consuming and costly. Items in the engine room are most preferred items looked for by ship repair yards and the shipping companies for replacement in their own ship.

The ship has to operate in a very harsh weather condition. Therefore all items on board a ship are very robust and have a longer lifespan. Due to this, the demand for such items from the consumer industry is very high and sometimes they are sold in the open market at a premium compared to the existing items locally made. 
Table 1. Key re-cycle components

\begin{tabular}{|c|c|}
\hline $\begin{array}{l}\text { Key Marine Equipments Obtained } \\
\text { from ships at Recycling yard }\end{array}$ & $\begin{array}{l}\text { Original Equipment Manufacturer/ } \\
\text { Representatives }\end{array}$ \\
\hline & $\begin{array}{l}\text { Cummins India, Wartsila India, MAN Diesel, } \\
\text { Rolls Royce, Caterpillar Marine }\end{array}$ \\
\hline Propulsion system & $\begin{array}{l}\text { Rolls Royce, HRP Asia Pvt. Ltd., Scana Volda } \\
\text { AS. }\end{array}$ \\
\hline Diesel generators & $\begin{array}{l}\text { Cummins India, Simpson and Co, Volvo } \\
\text { Penta }\end{array}$ \\
\hline Deck Cranes & Stan International \\
\hline Steering Gear & $\begin{array}{l}\text { Nicol and Andrew Engineering, Ultra Marine } \\
\text { Air Aids }\end{array}$ \\
\hline Navigational equipments & Schenker India, Jotron Phontech \\
\hline GMDSS Equipment & $\begin{array}{l}\text { Ultra Marine AIR Aids, ELECOME marine, } \\
\text { Schenker India }\end{array}$ \\
\hline AC Plants and Ventilation & Sevcon, Heinen \& Hopman Engineering \\
\hline Anti Healing Plant & $\begin{array}{l}\text { ASAP Marine, Arcum Engineering, Elcome } \\
\text { Marine Services }\end{array}$ \\
\hline Shaft Alternators & Leroy Somer \& Controls \\
\hline Anchor Chain \& windlass & $\begin{array}{l}\text { Ydcom Sales and Exports, Bhavani } \\
\text { Engineering, }\end{array}$ \\
\hline Life Saving Equipments & Vanson Engineering \\
\hline Signals & Schenker India \\
\hline Valves & $\begin{array}{l}\text { Malhar Engineering Works, Geeta } \\
\text { Engineering, Keystone India, Modimax } \\
\text { Engineers, VKM Valves Industries }\end{array}$ \\
\hline Fuel oil \& Lube oil Purifier & $\begin{array}{l}\text { Alfa Laval, Excel India, Hamworthy KSE } \\
\text { (India) }\end{array}$ \\
\hline Inter Communication System & $\begin{array}{l}\text { Stan International, Rajesh Metal Corporation, } \\
\text { Arkay Electronics \& Marine, Elektronik } \\
\text { Lab, Technip Industries, Asiad Marine } \\
\text { \& Engineering Works, Fastners India } \\
\text { Manufacturers }\end{array}$ \\
\hline Fire Fighting equipments & $\begin{array}{l}\text { Ardee Corporation, Hamworthy, KSE (India), } \\
\text { B E Pumps, Kirloskar Brother }\end{array}$ \\
\hline
\end{tabular}

\section{Indirect Utilization - Recycled Items}

Lead acid batteries are one of the major by-products generated out of the ship recycling process. The extracted lead acid batteries out of the ship recycling yard could be recycled to be used either in the shipbuilding industry or it could also be used in the general consumer industry. Lead acid batteries have very wide range of utilities in the automobile sector for starting, lighting and ignition of engine. It is also used as large power backup, supplies for telephone, computer centres, grid energy storage, offgrid household, electric power systems, etc. Lead acid batteries are also used in submarines, wheelchairs, electric scooters, electric vehicles, hybrid bicycles, etc. They have an advantage of getting recharged in a much lesser time. That increases their utility. India is highly dependent on import of lead acid batteries. 
Lubricants generated out of the waste lube oil collected from ships in the recycling yard could be re-refined and used after blending with other suitable additive. These can also be used by removing chemical impurities, heavy metals and dirt and used for industrial and automobile purposes. The other wastes such as furnace oils, boilers can be used in the secondary industry after recycling.

\section{Employment Generation}

It is an accepted fact that ship recycling industry is an employment generating industry. It provides lots of employment opportunities as well as business opportunities to various industries. The industry uses low amount of non-recoverable natural resources and is the only way for safe disposal of seagoing vessels.

Ship recycling industry, during its peak, generates over 40,000 direct employment opportunities and indirect employment for about of 1 lakh people. Current global economic ${ }^{6}$ slowdown and low freight rates have become a blessing for Indian ship recycling industry. There is a need to capitalise on it by creating large and suitable infrastructure to capture larger market share.

Ship recycling industry at its peak time generates direct employment to over 40,000 and indirect employment of 1 lakh people. In the past, during 2000 to 2003 industry was at its peak. The present global economic slowdown and low freight rates has become a blessing for Indian Ship recycling industry ${ }^{5}$. There is a need to capitalise on it in creating large and suitable infrastructure to capture larger market share. The economic activity at the ship recycling yards in India is again at the peak of their cycle.

\section{Future Prospects of Recycling}

In the history of Indian shipbuilding, even at the peak of the cycle, all the shipyards in India could not have consumed all of the material which has been generated during the lowest cycle of ship recycling activity. This is the scale at which the ship recycling industry of India operates. This benefit needs to be capitalized in a systematic way. The industry would have to capture all the items on a large scale and recycle them. Involvement of original equipment manufacturer would increase the credibility of process and the end product.

India has the least environment footprint. Primary reason for least environment footprint is that India has a great demand for each and every item, whether it is new or old. Inherently and traditionally, India does not follow the popular use-and-throw culture. Looking at the cultural prospects in the ship recycling industry, India would find higher usability of the scrap material brought along with ship to be recycled. This is one of the major reasons why the ship recycling industry is a sustainable or an environment ${ }^{12}$ friendly industry.

Indian ship recycling ${ }^{2}$ yards in Alang generate less than $5 \%$ of wastage. Every item is reprocessed to create utility. More than $95 \%$ materials of a ship is recycled and reused. Compared to traditional steel industry, this is better as far as the life cycle analysis goes.

Every ship would require being recycled after it has attained its economic life, hence recycling of ships would be a long term sustainable industry. The finished products generated out of first dismantling ships and then recycling it, could be used by steel industry, secondary steel industry and other ancillary industry supporting shipbuilding industry.

\section{Conclusion}

The convention for ship re-cycling ${ }^{8}$ has not yet been implemented; however the re-cycling of all components should be tested by authorized competent personal on specific test rigs prior re-certification for use. The draft policy for re-cycling of the components should be strictly regulated to avoid on board accidents leading to disasters at sea. The re-cycling process will assist in reducing the waste and lower the principle cost of a ship. The life cycle of each re-cycled component has to be issued "type approval" certificate for the component as same as issued by the component's manufacturer. The ship re-cycling industry would also ease the un-employment problems.

\section{Acknowledgement}

The author is grateful to AMET University, for all the encouragement and support received while working on this paper. 


\section{References}

1. Puthucherril TG. Ship breaking to Sustainable Ship Re-cycling. March 2010

2. Mishra P, Mukherjee A. Ship Recycling: A Handbook for Mariners. Narosa Pub House; 2009 Feb 15.

3. Andersen AB. Worker Safety in the Ship-breaking Industries. An Issues Paper. The International Labour Office. Switzerland: 2001.

4. Hadjistassou. International Maritime Organization: Rethinking Marine Environmental Policy. [Master Thesis]. Massachusetts Institute of Technology: 2004.

5. Krause K. End-of-life ships - linking European maritime safety to occupational safety on Asian scrap yards. In: R. Allsop, J. Beckmann, G.M. Mackay, editors. ETSC Yearbook 2005, Safety and Sustainability, Brussels. European Transport Safety Council; 2005.

6. Fayette L. The protection of marine environment - 1999. Environ Pol Law. 2000; 30(1-2)51-60.
7. Lauridsen FS, Krsitensen N, Cowi JS. Ship breaking in OECD. Denmark: Danish Environmental Protection Agency; 2003.

8. Mikelis N. Developments and issues on recycling of ships. Proceeding of the East Asian Sea Congress, Hainan; 2006 Dec; China.

9. Mikelis N. A statistical overview of ship recycling. Proceeding of the International Symposium on Maritime Safety, Security and Environmental Protection, 2007 Sep. Athens, Greece.

10. Rousmaniere P. Ship breaking in the developing world: problems and prospects. Int J Occup Environ Health. 2007; 13(4):359-68.

11. Vedeler KV. Cradle to Grave - Value Chain Responsibility in the Ship Scrapping Industry. 2006.

12. White I, Molloy F. Ships and the marine environment. Maritime Cyprus. 2001. 